\title{
Evaluation of potential antimicrobial chlorhexidine digluconate microencapsulated in model experimental dental biofilm
}

\author{
Giselle Medeiros da Costa One*, Allan de Jesus dos Reis Albuquerque*, Daniela Correia Cavalcante Souza, \\ Fabio Correia Sampaio \\ From 5th Congress of the Brazilian Biotechnology Society (SBBIOTEC) \\ Florianópolis, Brazil. 10-14 November 2013
}

\section{Background}

The formation of biofilm on the tooth surface is a result of the process of colonization of cariogenic bacteria, especially Streptococcus mutans, the main responsible for cariogenic (acid production) of dental biofilms [1]. The removal and chemical control of dental biofilm with chlorhexidine digluconate $0.12 \%$ (CLX) has been the most effective antimicrobial agent of choice clinic. However, despite its indisputable efficacy, no side effects such as darkening of the teeth, tongue and restorations, burning mouth and changes in taste. The formation of inclusion compounds CLX for the controlled release of the compound in a lower concentration could be a viable strategy to reduce these side effects without diminishing the therapeutic efficacy of the product [2,3]. Against this background, this study aimed to prepare nanocapsules CLX (processing aid) (1.2\%) in model spray drying using modified starch as the encapsulating agent, tested in biofilm model using bovine teeth.

\section{Methods}

The microbiological evaluation of in vitro antimicrobial activity of different formulations was made against S. mutans strain UA159 grown in artificial saliva, a model of biofilm produced in the flow cell. The biofilm on the teeth was exposed to nano-CLX, CLX Periogard ${ }^{\circledR}$ and standard laboratory for 2 minutes. Cell viability was measured by fluorescence LiveDeadBactLightTM Kit with dyes Syto ${ }^{\circledR} 9$ and Propidium Iodide.

\section{Results}

The results showed equivalence between efficiency and CLX laboratory Periogard ${ }^{\circledR}$, featuring both $0 \%$ percentage of S. mutans after treatment. The CLX nanocoated $(1.2 \%)$ showed significant efficiency at $90 \%$ cell death indicating controlled release of the drug. The model CLX nanocoated by spray drying, and modified starch as encapsulating agents when tested in a model of biofilm using bovine teeth showed good response when used as antimicrobial.

\section{Conclusions}

The molecular nature of chlorhexidine ensures its effectiveness in combating bacterial biofilms, and such activity is in fact already enshrined. However, the alternative formulation nanocapsulada allows an effective control of its release, ensuring control of the main process cariogenic bacteria, thereby reducing their undesirable aesthetic point of view, representing new alternative for the application and release of a single antimicrobial without the immediate need for new drugs.

\footnotetext{
Acknowledgements

Laboratory of Oral Biology.

Published: 1 October 2014
References
1. P D: Dental plaque as a microbial biofilm Caries Res 2004, 38(3):204-211.
2. Cortés ME, Sinisterra RD, Ávila-Campos MJ, Tortamano N, Rocha RG: The chlorhexidine:beta-ciclodextrin inclusion compound: preparation, characterization and microbiological evaluation. J Inclusion Phen Macrocyclic Chem 2001, 40:297-302.
3. Smith AW: Biofilms and antibiotic therapy: Is there a role for combating bacterial resistance by the use of novel drug delivery systems? Advanced Drug Delivery Reviews 2005, 57:1539-50.


doi:10.1186/1753-6561-8-S4-P86

Cite this article as: Costa One et al:: Evaluation of potential

antimicrobial chlorhexidine digluconate microencapsulated in model

experimental dental biofilm. BMC Proceedings 2014 8(Suppl 4):P86.

Submit your next manuscript to BioMed Central and take full advantage of:

- Convenient online submission

- Thorough peer review

- No space constraints or color figure charges

- Immediate publication on acceptance

- Inclusion in PubMed, CAS, Scopus and Google Scholar

- Research which is freely available for redistribution

Submit your manuscript at 